\title{
THE TARGET EXPERT SYSTEMS OF GEOLOGICAL ORIENTATION: THE CONCEPTION OF PROBLEM
}

\author{
D.P. Khrushchov ${ }^{1}$, O.P. Lobasov ${ }^{2}$, M.S. Kovalchuk ${ }^{3}$, \\ O.O. Remezova ${ }^{4}$, L.P. Bosevska ${ }^{5}$
}

${ }^{1}$ Institute of Geological Sciences of NAS of Ukraine, Kiev, E-mail: Khrushchov@hotmail.com Doctor of geological and mineralogical sciences, professor, senior research scientist.

${ }^{2}$ Freelance geologist, IT specialist, Kiev, Ukraine, E-mail: Lobasov_al@rambler.ru Candidate of geological sciences.

${ }^{3}$ Institute of Geological Sciences of NAS of Ukraine, Kiev, E-mail: kms1964@ukr.net Doctor of geological sciences, chief department of lithology.

${ }^{4}$ Institute of Geological Sciences of NAS of Ukraine, Kiev, E-mail: remezova-e@mail.ru Doctor of geological sciences, senior research scientist.

${ }^{5}$ Ukrainian Salt Research Institute, Artyomovsk, Donetsk region, Ukraine, E-mail: bosslara@gmail.com Candidate of geological sciences, senior research scientist.

The Problem of Implementation into Geological Practice of Target Oriented Expert Systems (TES) basing upon Principles of Geological Objects Complex Modelling based on Modern Computer Technologies with a Perspective of Artificial Intellect Elements introducing is considered. The Methodological basis of CES is Complex Evaluation of a Geological Environment by means of Integrated Model Construction of Defined Orientation.

Key words: Expert Geological Systems, Computer Modeling, Digital Models, geological environment.

\section{ЦІАЬОВІ ЕКСПЕРТНІ СИСТЕМИ ГЕОАОГІЧНОЇ СПРЯМОВАНОСТІ: КОНЦЕПЦІЯ ПРОБАЕМИ}

\author{
Д.П. Хрущов ${ }^{1}$, О.П. Лобасов ${ }^{2}$ М.С. Ковальчук ${ }^{3}$, \\ О.О. Ремезова ${ }^{4}$, Л.П. Босевська ${ }^{5}$
}

${ }^{1}$ Інститут геологічних наук НАН України, Київ, Україна, E-mail: Khrushchov@hotmail.com Доктор геолого-мінералогічних наук, професор, старший науковий співробітник.

${ }^{2}$ Незалежний геолог та IT спеціаліст, Київ, Україна, E-mail: Lobasov_al@rambler.ru Кандидат геологічних наук.

${ }^{3}$ Iнститут геологічних наук НАН України, Київ, Україна, E-mail: kms1964@ukr.net Доктор геолого-мінералогічних наук, професор, завідувач відділу літології.

${ }^{4}$ Інститут геологічних наук НАН Украӥни, Київ, Україна, E-mail: remezova-e@mail.ru Доктор геологічних наук, старший науковий співробітник.

${ }_{5}^{5}$ Украӥнський науково-дослідний інститут соляної промисловості (УКРНДІСІЛЬ), Артемівськ, Донеиька область, Україна, E-mail: bosslara@gmail.com

Кандидат геологічних наук, старший науковий співробітник.

Представлено проблему запровадження у геологічну практику цільових експертних систем (ЦЕС) геологічного спрямування, що базуються на принципах цільового комплексного моделювання геологічних об'єктів на основі сучасних комп'ютерних технологій з перспективою запровадження штучного інтелекту. Методологічною основою ЦЕС є комплексна оцінка геологічного середовища шляхом побудови комплексної моделі визначеної спрямованості. Ключові слова: експертні геологічні системи, комп'ютерне моделювання, цифрові моделі, геологічне середовище.

๑ D.P. Khrushchov, O.P. Lobasov, M.S. Kovalchuk, O.O. Remezova, L.P. Bosevska, 2015 


\title{
ЦЕАЕВЫЕ ЭКСПЕРТНЫЕ СИСТЕМЫ ГЕОАОГИЧЕСКОЙ НАПРАВАЕННОСТИ: КОНЦЕПЦИЯ ПРОБАЕМЫ
}

\author{
Д.П. Хрущев ${ }^{1}$, А.П. Лобасов ${ }^{2}$, М.С. Ковальчук ${ }^{3}$, \\ Е.А. Ремезова ${ }^{4}$, Л.П. Босевская ${ }^{5}$
}

\begin{abstract}
${ }^{1}$ Институт геологических наук НАН Украинь, Киев, Украина, E-mail: Khrushchov@hotmail.com

Доктор геолого-минералогических наук, профессор, стариий научный сотрудник.

${ }^{2}$ Независимый геолог и IT спещиалист, Киев, Украина, E-mail: Lobasov_al@rambler.ru Кандидат геологических наук.

${ }^{3}$ Институт геологических наук НАН Украины, Киев, Украина, E-mail: kms1964@ukr.net Доктор геологических наук, профессор, заведующий отделом литологии.

${ }^{4}$ Институт геологических наук НАН Украинь, Киев, Украина, E-mail: remezova-e@mail.ru Доктор геологических наук, старший научный сотрудник.

${ }^{5}$ Украинский научно-исследовательский институт соляной промышленности (УКРНИИСОЛЬ), Артемовск, Донецкая область, Украина, E-mail: bosslara@gmail.com Кандидат геологических наук, стариий научный сотрудник.
\end{abstract}

Представляется проблема внедрения в геологическую практику целевых экспертных систем (ЦЭС) геологической направленности, базирующихся на принципах целевого комплексного моделирования геологических объектов на основе современных компьютерных технологий с перспективой введения искусственного интеллекта. Методологической основой ЦЭС является комплексная оценка геологической среды путем построения комплексной модели определенной направленности.

Ключевые слова: экспертные геологические системы, компьютерное моделирование, цифровые модели, геологическая среда.

\section{Introduction and problem definition}

There has been registered a «genre crisis» on the development of management systems in the field of human geological activity, i.e. the versatile use and protection of geological environment so far. This crisis is a contradiction between the growing economic, social and environmental challenges, supported by technological progress, and a state of analytical support for appropriate management actions. Insufficient efficiency of traditional methods of data providing about geological (both humanmade and geological) objects and processes based on the analog methods of their modeling (although with the certain role of computer technologies) is in basis of the indicated contradiction.

Overcoming of this crisis is possible by introduction into geological practice of the target oriented expert systems (TES) being based on principles of target complex modeling of geological environment by means of modern computer technologies with the elements of artificial intelligence. Thus, the purpose of this work is a projected elucidation of the stated problem.

To achieve this purpose the following tasks are:

- submission of principles, methodology and methods of the TES creation;

- denotation of the TES basic directions, their tasks, structure and content;

- demonstration of existing developments;

- denotation of prospects for this scientific direction.

The results of long-term researches by composite authors team in the area of geological structure, material composition studies and modeling of sedimentary formations have formed the foundation for the statement of this problem. Researches were mainly conducted for some salt-bearing, red-colored terrigenous and placer (titanium-zirconium and auriferous) formations. Lately, specific ecological aspects have also become an additional important subject for study and applying in modeling. 
Definition of expert systems as «target» implies its focused orientation to solve specific practical problems of high complexity related to the multipurpose subsoil use (extraction of mineral resources, underground construction) and geological environment protection.

\section{Pre-history of the idea}

The idea of the TES creation came as a natural result of long-term researches in the area of geological objects modeling. The first stage was creation of conceptual structural-lithological models (SLM) of geological objects for certain types of sedimentary formations that allowed to develop the effective principles of their system structurization. The received result showing the method high informative and prognosis effect has logically resulted in a conclusion about possibility of further development of these functions by means of geoinformatic technologies application. Principles of digital SLM (DSLM) creation have been developed on the base of such technologies by our authors' group. The results of digital modeling have also confirmed expectations, and examples of some models showed the high level of technical, informative and prognosis functions [Хрущев и др., 2010; Босевська та ін., 2010; Khrushchov et al., 2010b]. However, it became very clear that the DSLM was able to be effective for the geological objects of certain level of complication with the decision of the limited number relatively simple tasks belonging to resource and mining geological directions.

Later a real situation put the necessity of complex problems decision embracing several aspects of a geological environment handling; there are resource, construction and environmental ones, etc. (for example, Solotvyno rock salt deposit, Kalush mining and industrial district, where the problems of mines flooding were complicated by surface catastrophic deformations). Such complicated problems can only be solved by means of complex target models creation embracing a few subject subordinate models (being based on DSLM). Such complex model is the basis for the TES creation.

However, the offered complex model has a vulnerable characteristic: a procedure of subordinate models connection by experts pro- vides any receipt of more or less grounded decisions, but expert-man possibilities do not allow to embrace a plurality of model components arising in process of connecting models and some increasing uncertainties. Thus, at this stage our complex model can be considered as unaccomplished in terms of the universally recognized canons of expert systems.

That is why we need to solve the problem tasks on the basis of expert analysis of said step results, i.e. the further evolution of this scientific direction already becomes the subject of geological cybernetics. Accordingly, identification of the expected result in the rank of expert system (ES) is valid in the classic sense.

\section{Methodology and methodical approaches}

$\mathrm{ES}$ is the direction of artificial intelligence technologies - the concept from the list of the subjects of cybernetics as a science about the management system's.

Principles of the ES creation are being developed from $1960^{\text {th }}$ with the purpose of decision of the highly specialized plural tasks. Some existing determinations of expert system are the following:

ES is a class of computer programs, which give advices, conduct an analysis, execute a classification, give any consultations, etc. They are oriented to the solution of challenges without a man-specialist for carrying out expertise [Таунсенд, Фохт, 1990].

ES is a software tool using expert knowledge for effective tasks decision in a certain subject domain intended for a professional user of average level (expert) [Субботін, 2008].

ES are based on knowledge, namely, on its two structural elements: knowledge base and apparatus of logical decisions. In a methodological plan ES includes two fundamentals: 1) traditional computer database processing; 2) computer processing of complex of expert data and rules (knowledge bases). Otherwise, not only formalized and algorhythmizated knowledge as some mathematical models of processes (dynamic submodels) and objects properties (static submodels) are used but also system of information and logical rules used by specialists non-obviously for the problem solution. The special mathematical apparatus im- 
itating expert work has been created. Modern, object-oriented programming languages of high level are used for solution of standing tasks.

Thus, the ES structure is the following:

1) conventional database about object properties;

2) mathematical methods for the data processing and receipt of the determined or statistical models of objects and processes;

3) knowledge base containing the expert rules;

4) logical and proper mathematical apparatus for decision.

The typical expert system structure is represented on the Fig. 1 [Капралов и др., 2004]. It should be noted, medicine diagnosis, psychological testing and chess program expert systems are the most developed by today. However, ES of geological direction differ substantially from other systems. One of the most general differences is that a professional-expert (but not a user-customer) is the actual their user because their final product is no decisions, but a semi-finished product being an initial conclusion for decisions making by an expert only. The second most important difference is that geological information is exactly represented by quantitative information. That is why the digital object model has been a base of ES. Obviously, this second difference explains the delay in development of ES in the field of geology.

The methodological principle of geological target ES creation is a connection of two theoretical directions (disciplines): geological computer modeling and geological cybernetics.

The geological computer modeling is the creation of the computer virtual 3D reflection of geological objects and geological processes (processes taking place in a geological environment).

A geological object is a site of the Earth's crust of a certain size, selected for any target geological study [Субботін, 2008].

The DSLM is an example of computer model of a geological object; it is virtual 3D reflection of geological object, containing its structural and qualitative descriptions [Xpyщев, Лобасов, 2006].

The most part of well-known examples of processes modeling refers to hydrogeological direction. There is the «Nedra» system developed by Institute of cybernetics and Institute of geological sciences of NAS of Ukraine in domestic practice.

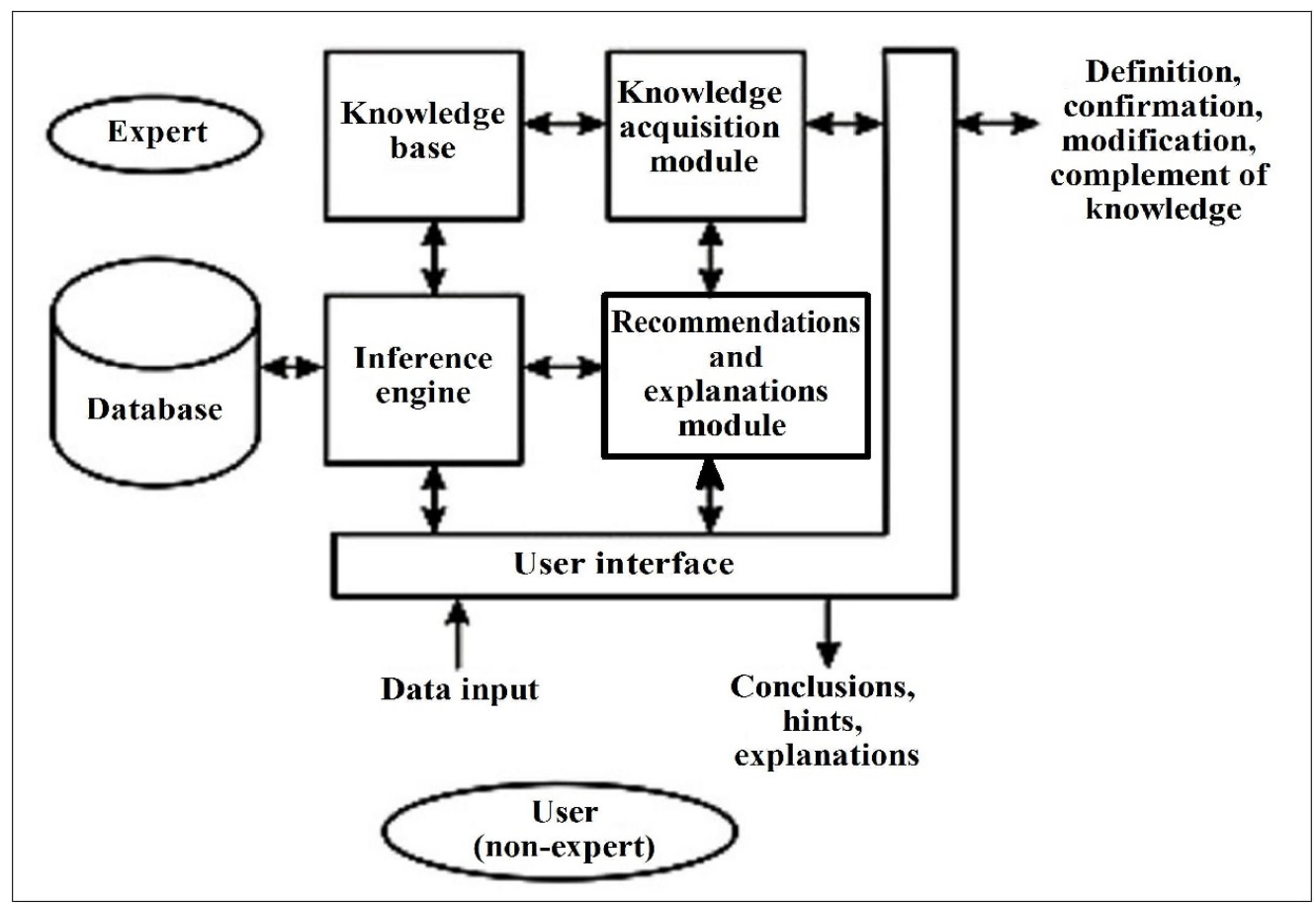

Fig. 1. Structure of expert system (http:/ itteach.ru/predstavlenie-znaniy/ekspertnie-sistemi) 
Geological cybernetics (originally, geocybernetics) is «...the branch of knowledge about structure regularities of the complicated selforganizing and self-developing natural and natural-human-made systems and passing of managing processes in them», otherwise, «... about general acts of storage, transmission and information processing in the systems that are subject of geological and geographical sciences» [Кадетов и др., 1989].

Obviously, it should use artificial intelligence technologies being the subdiscipline of cybernetics to create the target geological ES in the proper modification. These technologies tasks correspond to items 3 and 4 of the ES structure given above. Understanding of «knowledge base» (item 3) must be based on the development of "geological knowledge" concept. According to the definition by A.S. Smirnova (1985), the geological knowledge is the aggregate of all documented information on composition, structure and history of Earth's development [Смирнова, 1985].

Thus, the knowledge base applied to the geological ES is the collection of knowledge about structure regularities and material composition of geological objects as systems, interrelationship between the elements of these systems and neighbor systems, and an interaction between the systems and between their elements and, finally, development (evolution) of first and second ones.

It should be reminded a database in geology is the complete set of specific data on structural, material and other features of specific geological objects (for static modeling) and parameters of processes in a geological environment (for dynamic modeling).

From the methodological point of view, the complex evaluation of geological environment of the marked object lies in the TES basis. A complex model is the execution tool of this evaluation. The methodological basis of modeling is a consideration of geological objects as systems that is characterized by the external and inner structures with their stages in the development and certain relationship with surrounding systems. Proceeding from this position, two types of models (static and dynamic) are allocated. The structural and lithological models belong to the number of static. Dynamic ones are: hydrodynamic, paleotrans- port, migratory-geochemical and etc. From point of subject, the subordinate models, composing complex model correspond to certain geological sciences (disciplines) or their combinations. The most used models such as structural and lithological (SLM), hydrogeological, geomechanical et al are considered below.

Now the development of separate subject models has already been a routine task. However, their connection for creation of complex target models already represents the task of a higher grade. The special direction is submitted by a new investigation named «structural and lithological modeling with the geological and dynamic filling» or "retrospective-state structural-lithological modeling» (A. Laviorov et al., 2014). That modeling has been executed on the example of heavy minerals placers (special fundamental project). When performing of this investigation, an attempt to add dynamic aspects of placers formation to prepared SLM was carried out, that should improve a prognosis function of modeling. Different types of task solutions are considered below.

There have already been examples of ES of geological direction in world practice such as DIPMETER ADVISOR, DRILLING ADVISOR, ELAS, LITHO, PROSPECTOR. The majority of them have technological and geophysical orientations. We know the only ES example PROSPECTOR, which advises geologists during ore deposits prospecting.

\section{Principles of development and functional possibilities of geological objects digital models}

Procedural schemata and expected results of different subject and target directions modeling are examined. The procedural scheme of DSLM is most developed [Хрущев и др., 2010; Khrushchov et al., 2012]. It embraces the implementation of the following stage tasks: development of model's structural component, lithological filling of structural elements, elaboration of programmatic tools for decision of tasks connected with concrete DSLM, elaboration of programmatic tools for model visualization and realization.

A model can be general geological informative and target-oriented. At creation of target model the add-on of its general structural- 
lithological part by the initial data is carried out. Composition of target model database is determined by the purpose of modeling. If it is prognostication of minerals, controlling factors can be entered in to a model such as lithofacies, facies, geochemical and mineralogical indexes, zones of lithogenesis stagewise, contents of useful component, and also other data, related to established conditions of its distribution. If a formulation of the problem of geological environment selection for any underground construction takes place, it need to take into account those factors, which characterize physical-mechanical properties of massif (these factors are used for calculation of long-term sustainability and insulating ability according to the technical requirements to construction type).

The first generation of SLM are static; however, they are sufficiently effective to address the issues of prognostication, prospecting and exploitation of sedimentary formations deposits. Adequacy and resolution of prognosis function can be increased by introduction to the modeling of dynamic aspect that is our purpose while creating of the second generation of SLM.

The best example of that is current result of a new authors' product «structural-lithological modeling with the geological-dynamic filling" see above. Methodological basis of this product is different scales progressive stage modeling; and different stages of modeling are characterized by different content of structural-lithological and geological-dynamic components.

The complexes of traditional subject methods, reflecting the geological-dynamic aspects of mineral concentrations forming mainly correspond to the small- and the medium- scale stages of structural-lithological modeling. Medium and the large-scale stages of structure-lithological modeling are complemented (except for traditional dynamic constructions) with the authors' complex of methodological technique including two most effective such as method of masses balance and diffusive-convectional model (Lalomov, 2010).

For resolution the first from them corresponds to the small- and medium-scale modeling (regional and zonal levels), and the second - mainly large-scale and detailed mod- eling (from zonal to the local level, i.e. of ore fields and separate deposits accordingly).

The geomechanical models are intended for evaluation and prognostication of geomechanical state and processes in massif. Their basis is also initial data of SLM and additional data obtained on the basis of established interdependencies between lithological features and physical-mechanical properties of rocks [Хрущев, Оксенкруг, 1983].

The hydrogeological models are dynamic essentially, i.e. they are the subject of hydrodynamics. The main task of hydrodynamics is determination of dynamic properties of groundwater; but it in combination with hydrochemistry also serves as a basis for migratory schemata, and also schemata of karst, landslides and other dangerous geological phenomena development. Taking into account that the filtration properties of rocks are the determinative factor of hydrodynamics, the role of SLM is further enhanced since it exactly represents volume characteristic of structural and matter matrix, in which groundwater streams are moving. It should be noted that the hydrogeological modeling is the most developed and methodologically grounded direction of the geoinformatics; it has been widely described in scientific literature.

Functional possibilities of models are determined by their subject as it applies to the TES tasks. The DSLM example is considered to demonstrate. Functional possibilities of this model are shown for the static, dynamic and retrospective aspects represented by proper submodels (Table 1). As shown in Table 1 the functional possibilities of modeling for direction of the mineral resources use include the following. For static submodel:

- selection of favorable facies (and genotypes) for ore-forming processes (sedimentation and sedimentation-diagenetic types);

- selection of favorable lithofacies and lithotypes for localization of epigenetic ore body, selection of reservoir rock;

- establishment of the spatial distributing of geochemical barriers and other ones in connextion with underground construction.

For dynamic submodel:

- prognosis of realization of favourable lithofacies and facies (for ore deposits);

- prognosis of reservoir rocks realization (for the deposits of hydrocarbons). 
Table 1. Structure and functional possibilities of structural and lithological model

\begin{tabular}{|c|c|c|}
\hline Static submodel & $\underset{\text { for selection }}{\stackrel{\text { Possibilities }}{\longrightarrow}}$ & $\begin{array}{c}\text { Facies (and genotypes) favorable for ore-forming } \\
\text { (sedimentation and sedimentation - diagenetictypes) } \\
\text { Lithofacies and lithotypes favorable for localization } \\
\text { of epigenetic ore bodies and beds of collectors } \\
\text { Distribution of barrier properties of geological- } \\
\text { geochemical environment }\end{array}$ \\
\hline $\begin{array}{l}\text { Dynamic submodel (open } \\
\text { systems, interaction of quasi } \\
\text { closed systems } \\
\text { and open systems) }\end{array}$ & $\underset{\text { for prognostication }}{\stackrel{\text { Possibilities }}{\longrightarrow}}$ & Realization of favorable facies \\
\hline \multirow{2}{*}{$\begin{array}{l}\text { Submodel of interaction of } \\
\text { system with other systems } \\
\text { (all are quasi closed systems) }\end{array}$} & $\underset{\text { for prognostication of }}{\stackrel{\text { Possibilities }}{\text { collectors realization }}}$ & Ore bodies Deposits of hydrocarbons \\
\hline & $\begin{array}{l}\stackrel{\text { Possibilities }}{\underset{\text { for forecasting of }}{\text { pollution behavior }}}\end{array}$ & Modeling of geological environment pollution \\
\hline
\end{tabular}

For direction of geological environment protection the possibilities of static submodel include revealing of the spatial distributing of physical-mechanical, barrier properties in geological environment; and for submodel of model systems interaction - a prognostication of dynamics of contamination spread and other dynamic processes are also included.

It should be also noted that DSLM is a matrix basis for development of subordinate rank models of dynamic orientation characterizing the processes of heat-and-mass transfer (hydrogeological, thermalphysic, super imposed processes).

\section{Principles of complex models development}

The target complex model must reflect as a certain subject interest (resource, mining, ecological) as the necessary aspects for effective realization of the program actions. These aspects are represented by the proper subordinate models. In a methodological plan the integration of subordinate models (submodels) reflects is dynamic constituents of systems or their inner structure elements interrelations. In a plan of different theoretical models of geological objects the procedure of models uniting reflects also different intercommunications, interaction, processes. The row of the subordinate models used for construction of complex target models can be very wide. Their functional role in a complex model is defined, coming from their subject. For example, seven basic subject models are in composition the theoretical complex ecological-mining-geological model of geological environment evaluation for placing of radioactive wastes isolation objects (storage of geological type), such as: structural-tectonic, lithological, geomechanichal and engineeringgeological, geochemical, thermophysical, hydrogeological and hydrogeological migratory [Khrushchov, Tabachny, 2001].

Combining of subordinate models is an untraditional task due to substantial growth of quantity of elements, factors and events (scenarios).

\section{From a complex model to TES: methodological approaches}

If we consider the complex model as the basic one of TES, from the methodological point of view it (model) must display such the following features of the explored object:

- internal and external structure, and qualitative adjectives of object's elements (static aspects);

- dynamic aspects of object characterization as a system, which display its (system) formation and establishment (retrospective modeling), and also interaction of inner elements of the system as well as its interrelations with the surrounding systems, i.e. functioning of the system with the function of prognostication. 
The reflection of these features is reached by procedure of the complex model construction by connection of subject models, as subordinate (II hierarchical rank). During realization of this procedure there exist the following difficulties:

- significant increase of number of elements in inner structure of the system;

- significant increase of number of the processes being entered into the modeling and synergism effects caused by them.

Growth of quantity of uncertainties and, accordingly, change of correlation of the model's determined and probabilistic constituents becomes the consequence. Obviously formalization of certain part of elements of such a complicated system already can be ambiguous. All the more so it concerns the block of decision making. Thus, at the stage of integration of models there is the sharp change of formalizing (computerized) and expert constituents, i.e. qualitative transition from the computer modeling to the modeling with participation of cybernetic constituent takes place.

An expert constituent is based on the substantial analysis of the received results, to the consistency check of them to existent theoretical ideas of this subject domain, often informal and not even formalizable, and can result in the awareness of necessity of model regularization at the level of basic data and reiteration of separate stages or the complete cycle of modeling process. In addition, the target decision can be the product of qualitative expert analysis of the numerical results got from the subordinate subject models of geological object complex model. The qualitative expert analysis can be realized as the complex of procedures for treatment of expert rules base (knowledge bases). According to definition such a system consisting of the object database, knowledge base and mathematical tool of knowledge base treatment is ES, in our case it is the TES of geological object.

Coming from the resulted definitions, the ES competence is determined by adequacy of geological rules on which the subject and complex models of geological objects are built, and also by adequacy of factographic basis and its taxonomic structure.

Pragmatism of the offered methodology consists of the following possibilities of geological objects evaluation:

- static prognostication of useful properties;
- dynamic prognostication: 1) the increasing of resolution capability of static modeling by a path of retrospectively-dynamic constituent introduction; 2) dynamic prognostication of properties changes of geological environment in time.

In whole, the marked possibilities mean the informative providing for solutions of resource, building and ecological problems in the field of geological environment multipurpose use and protection.

\section{TES typification and content}

It is possible to outline three conceptual functional directions of TES: 1 ) use of raw material resources; 2) underground construction; 3 ) protection of geological environment. Since the complex model underlies the TES basis, it can consist of some subject models (Table 2). The complex of models for concrete object is determined by the subject (by the system of measures) of this object handling.

For different directions and separate types of ES the different complexes of models are inherent. According to the system destination, such separate blocks are singled out: resourcegeological, resource-mining-geological, mining-geological, ecological-mining-geological, ecological-geological.

The complexes (sets) of models (and their content) significantly differ within the limits of the outlined groups and also depending on the purpose of ES.

According to considered above typification of main directions of geological activity, proper to them the TES directions and complex models respective to the last we can represent the principlal TES schemes. On the first stage being based on experience of construction of digital subject models and complex target models, we will mark that the last already are the TES of incomplete type (without the elements of artificial intelligence). Such definition needs to be considered valid by virtue of their complex character and effectiveness.

Nipping in ahead, we must represent the principle scheme of the TES for geological problem of complete type, which is built on the basis of specificity of geological objects and geological knowledge, taking into account the systems of type decisions, and it is universal for all geological activity directions (Fig. 2). 
Table 2. The typization and content of complex target models in basic directions of geological activity

\begin{tabular}{|c|c|c|}
\hline Direction of geological activity & Direction of complex model & Determinative subject models \\
\hline \multirow[b]{2}{*}{ 1. Extraction of mineral resources } & $\begin{array}{l}\text { Resource-geological } \\
\text { (open pit mining) }\end{array}$ & Structural and lithological \\
\hline & $\begin{array}{l}\text { Resource-mining-geological } \\
\text { (mine and geotechnological } \\
\text { extraction) }\end{array}$ & $\begin{array}{l}\text { Structural and lithological, } \\
\text { geomechanical, } \\
\text { hydrogeological, etc. }\end{array}$ \\
\hline $\begin{array}{l}\text { 2. Undergroung building: } \\
\text { 2.1. Objects with man's access }\end{array}$ & Mining-geological & $\begin{array}{l}\text { Structural-lithological, geomechanical, } \\
\text { hydrogeological, thermalphysic, etc. }\end{array}$ \\
\hline $\begin{array}{l}\text { 2.2. Underground storages } \\
\text { (reservoirs) }\end{array}$ & Mining-geological & $\begin{array}{l}\text { Structural-lithological, geomechanical, } \\
\text { hydrogeological, thermalphysic, etc. }\end{array}$ \\
\hline $\begin{array}{l}\text { 3. Geological environment } \\
\text { protection: } \\
\text { 3.1. Territories of mining } \\
\text { enterprises action }\end{array}$ & Ecological-mining-geological & $\begin{array}{l}\text { Structural-lithological, geomechanical, } \\
\text { hydrogeological, etc. }\end{array}$ \\
\hline $\begin{array}{l}\text { 3.2. Territories of other violations } \\
\text { of geological environment (pollu- } \\
\text { tion by toxic substances, etc.) }\end{array}$ & Ecological- geological & $\begin{array}{l}\text { Structural and lithological, } \\
\text { hydrogeological (migration } \\
\text { including), etc. }\end{array}$ \\
\hline
\end{tabular}

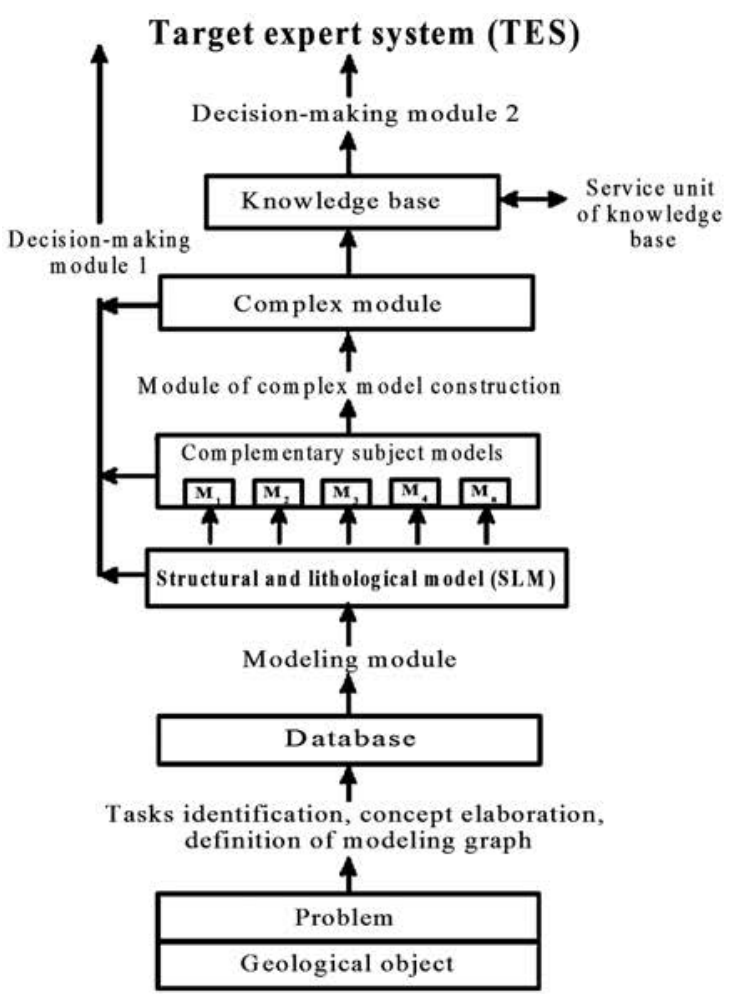

Fig. 2. Principal scheme of geological problem TES

As general schemes of TES of different directions in some elements repeat oneself, in order to avoid repetitions we show those their parts, which are individual, i.e. do not repeat oneself in TES of other directions. Such are the digital complex models with the proper sets of complementary subject models. It is below given a list over of complex models schemes with indication of aims and tasks (according to direction of geological activity).

1. Use of mineral resources. Purpose: information-analytical providing of types of (step) of R\&D: prediction - prospecting exploration - exploitation.

1.1. Resource-geological subdirection (for the open pit operation of mineral deposits) (Fig. 3, a)

1.2. Resource-mining-geological subdirection (underground operation of deposits) (Fig. 3, b)

2. Underground construction, including underground construction within salt structures

2.1. Storages of power resources (oil, gas, oil products) and some other materials (Fig. 3, c)

2.2. Repositories of toxic wastes (Fig. 3, c)

3. Protection and remediation of geological environment.

3.1. Remediation of dangerously contaminated geological environment (Fig. 3, d).

The TES tasks: 1) ascertainment of geological environment properties from point of projected methods of the object remediation; 2) substantiation of decontamination methods selection.

3.2. Disturbance of geological environment in territories of mining activity (it is shown an example of scheme of the TES complete type (Fig. 4).

Tasks of TES: 1) management of degraded territories as a result of mining activity; 2) management with the rest part of mineral deposits reserves. 
Discussing the results.

Examples of a target complex models development as a basis

for the TES creation

Nowadays some examples of DSLM have already been developed. According to the direction of mineral resources use, the DSLM for several typical placer ilmenite deposits (Zlobychi, Krasnokutsk, Motronovka, Tarasovka) and auriferous mineral deposits (Kanev-Zvenygorod prospective area, Balka Shyroka and Dnieprovske gold-ore deposit) are demonstrated. According to the direction of geological environment protection, the examples of two geological objects of salt mining activity, wherein complicated ecological situation has been taken place are shown below (Solotvyno rock salt deposit, Transcarpathia, and Kalush mining industrial district, Precarpathians). Descriptions of models have been resulted in a number of our publications.

Placers ilmenite deposits. Creation of DSLM for a number of this kind deposits demonstrates the provision of the following tasks solution:

- ascertainment of ore bodies spatial distribution, tracing of their correlation with lithofacies and facies, genotypes etc. (Fig. 5,A);
- automatic calculation of reserves on the fixed grade of ore component $(Q$ and $C$, see Fig. 5, A);

- working of the complex method of prognostication for deposits of this type.

In addition, the deposit model provides the basis of the part of technological tasks solution by means of ascertainment for the spatial distributing of granulometric parameters, clay content, harmful minerals and also determining of selective mining conditions for deposit (the task of related technological model).

Auriferous placers. The DSLM of KanevZvenygorod prospective area has provided the decision of the following tasks: the ascertainment of regularities of facial, lithofacial, paleorelief association of mineralization; the selection of prospective areas.

The DSLM of gold deposit Balka Shyroka has shown the following results:

- ascertainment of spatial distribution of gold, silver and copper in relation to of crust of weathering zonality;

- ascertainment of regularities of facial and lithofacial localization of mineralization in overlying strata;

- allocation of perspective areas [Хрущев и др., 2010].
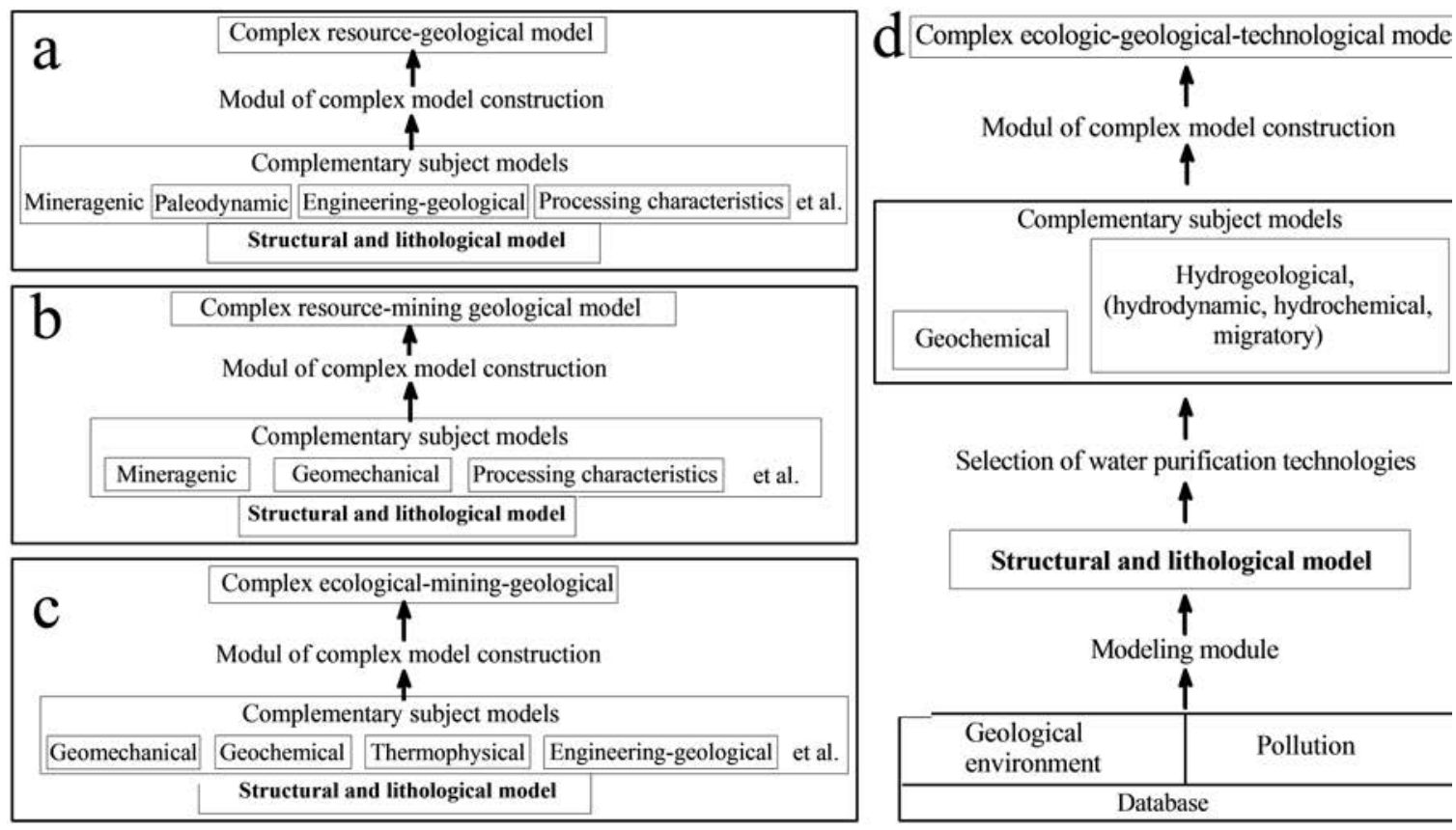

Fig. 3. Schemes of multipurpose complex models for various subdirections of geological environment use: a - for resource-geological subdirection; b - for resource-mining-geological one; c - for ecological-mining-geological one; $d$ - for ecological-geological-technological subdirection (environment remediation) 


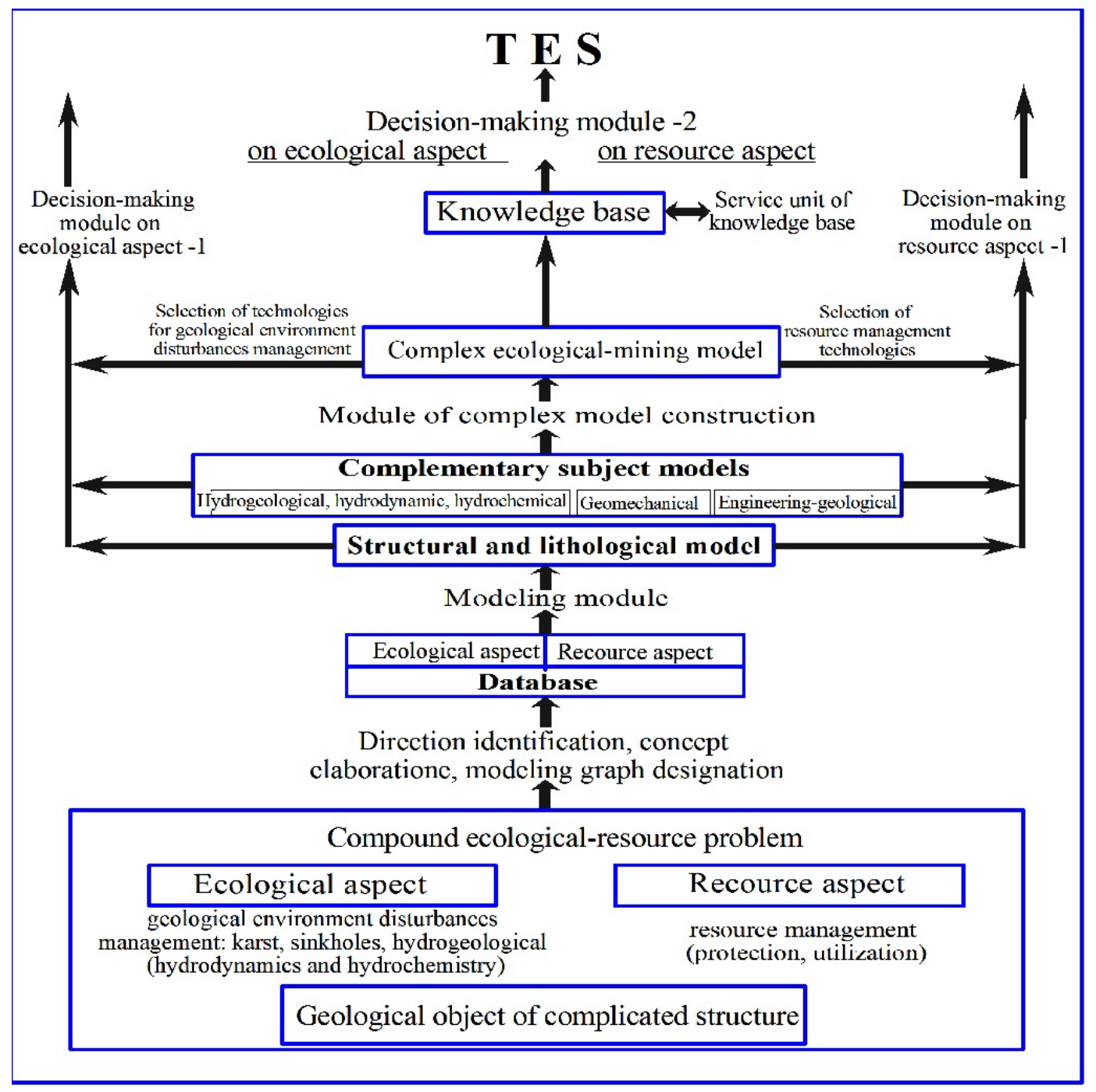

Fig. 4. Scheme of the TES for handling with the disturbed territories resulting from mining activity

These resulted examples testify that for the considered types of deposits and ore occurrences, the structural-lithological modeling is the basic self-sufficient constituent of future TES, which are intended for providing of decisions for prevailing part of the tasks, aimed at development of these deposits.

The examples of the TES preparation for territories of salt mining activity in connection with ecological problems are also shown below. The methodology of target modeling for territories of salt mining activity characterized with ecological problems is based upon the identification of biosphere disturbances caused with technogenous impact upon salt massifs [Khrushchov et al., 2010a; Khrushchov et al., 2012].

Solotvyno rock salt deposit. Here an emergence ecological problem is related to territory of activity of the State Enterprise «Solotvyno salt mine». This emergency environmental situation development has resulted in a flooding of two functioning rock salt mines due to intensive salt karst with formation of enormous sinkholes and other concomitant deformations of surface.

For administrative decisions providing as the main analytical tool we offered construction of complex ecological-mining-geological model. This model must include three constituents such as structural-lithological, hydrogeological and geomechanical-engineering-geological ones.

The DSLM of Solotvyno rock salt structure has been completed so far. It provides the following:

- ascertainment of the physical-mechanical and barrier properties spatial distribution in salt massif environment (assignment of initial data for the geomechanical and hydrogeological modeling); 

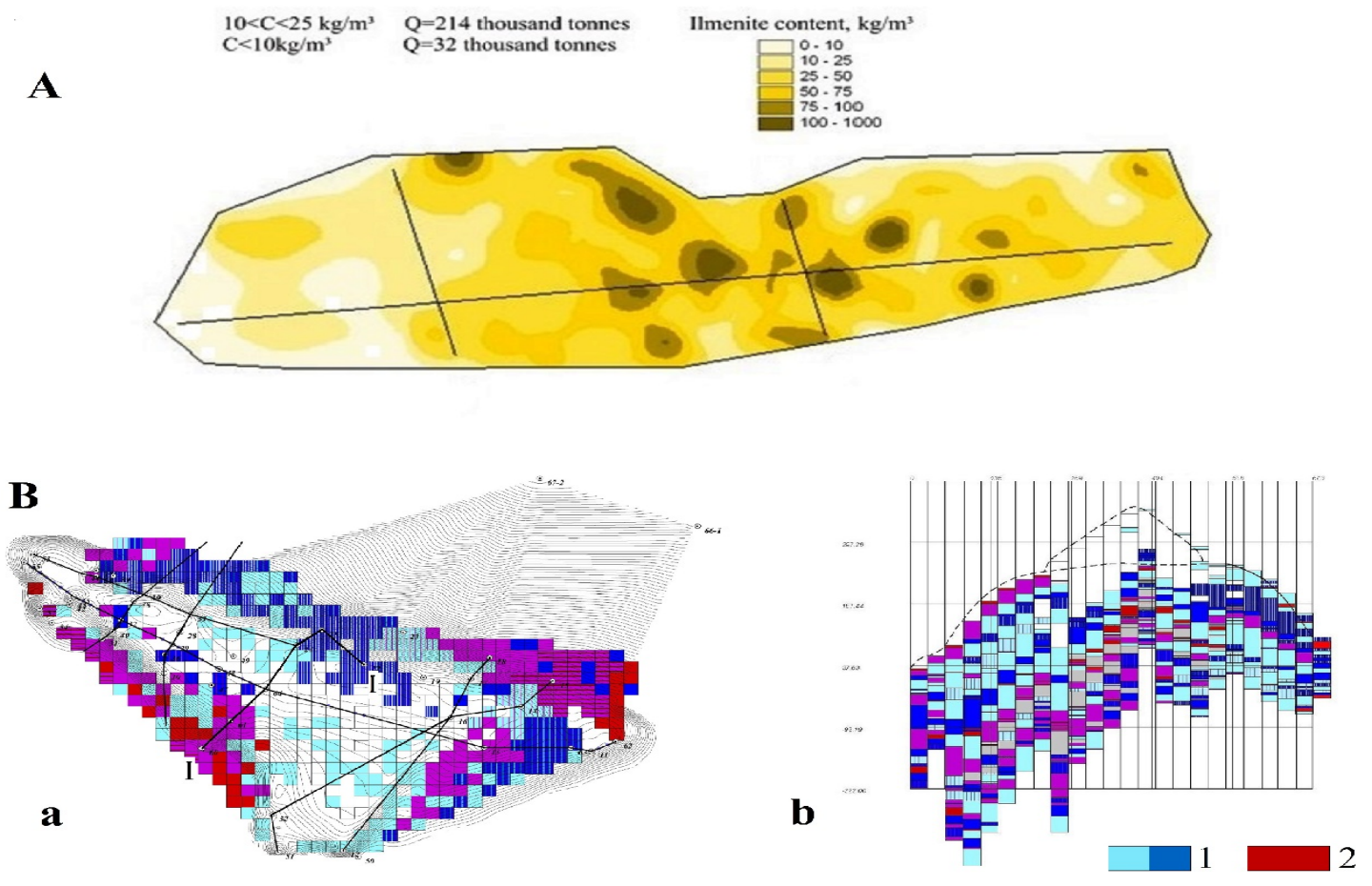

Fig. 5. Visualization of digital models: A - Zlobychi deposit of ilmenite; distributing of content and calculation of ilmenite reserves in a crust of weathering; B - Solotvyno rock salt deposit with displaying of favorable (1) and dangerous (2) characteristics of rock salt for deposit exploitation and underground facilities construction: a) horizontal section, abs. elev. $+50 \mathrm{~m}$; b) section on line I - I

- ascertainment of the spatial distributing of petrographic and geological production types of rock-salt (for further ecological safety multipurpose use of this salt body (Fig. 5, B);

- clarification of relief of salt massif surface.

Hydrogeological and geomechanical-engineering-geological models must be constructed for decision of the proper subject questions about the mechanism of development and prognosis of dangerous geological phenomena.

Elaboration of complex ecological-mininggeological model has to provide the following:

- complex evaluation of the salt massif state;

- drafting of prognostic map of dangerous geodynamic processes development;

- elaboration of monitoring scheme (geomechanichal, hydrogeological, etc.);

- substantiation of measures on limitation of dangerous geological processes consequences;

- substantiation for choice of promising sites for further deposit underground use.

Territory of the Kalush mining industrial district. The emergency environmental situation development within the territory of the Kalush group of potassium salts deposits has resulted in substantial consequential adverse effects. There are a flooding of potash mines and open pits; progressive development of ground subsidence and collapse threatening buildings and other facilities; progressive salinization of the geological environment including groundwater, rocks and soil; prospect of high mineralized brines inrush from open pit into a small river, threat of tailing pool destruction and release of damaging substances into the environment.

Presently we have elaborated the program of geological environment modeling for this territory. The tasks of the contemplated models are as follows.

Structural-lithological model:

- spatial distribution of lithofacial complexes;

- description of their morphology, material composition, structural and textural signs, lithotypes singling out.

A model gives initial data for elaboration of hydrogeological and geomechanical-engineering-geological models, taking into account two directions: resource and ecological).

Hydrogeological model:

- construction of hydrodynamic schemes with presentation of sources of water and areas 
of unloading, prognosis of regime changes on possible scenarios;

- construction of hydrochemical schemes with displaying of forming and conditions changes of main parameters, prognosis of hydrochemical parameters changes on possible scenarios with ascertainment of salt and other types of contamination in aquifers.

Geomechanichal engineering-geological model:

- modeling of bearing capacity and longterm stability of any elements of the object's human-made and geological system;

- modeling of deformations of the earth's surface and main elements of the object anthropogenic-geological system;

- prognosis of dangerous geological processes (subsidence, sinkholes, landslides) manifestations.

The necessity of account of a site foldblock structure is the peculiarity of the stated models elaboration. Thus, the constructions have been conducted on certain tectonic blocks. In turn, it determines the leading role of structural-lithological model.

A complex ecological-mining-geological model must display all informative and prognosis data of the considered models, namely:

- state and prognosis of dangerous geological phenomena including geodynamic one;

- state and distribution prognosis of salt and concomitant contamination in aquifers and geological environment, and also surface waters

\section{References}

1. Кадетов О.К., Колесников А.И., Кравцов B.B. Геоинформатика и геокибернетика - два направления системных исследований Земли. В кн.: Системный подход в геологии: Сб. науч. тр. Москва: Наука, 1989. С. 115-121.

Kadetov O.K., Kolesnykov A.I., Kravtsov V.V., 1989. Geoinformatics and kinematics - two directions of system researches of Earth. In: Systems approach in geology: Collected papers. Moscow: Nauka, p. 115-121 (in Russian).

2. Капралов Е.Г., Кошкарев А.В., Тикунов B.C. Основы геоинформатики: Учеб. пособие для студентов / [под ред. Тикунова В.С.]: В 2-х кн. Москва: Академия, 2004. Кн. 2. 480 с.

Kapralov E.G., Koshkarev A.V., Tikunov V.S., 2004. Geoinformaticf undamentals. Moscow: Academia, book 2, 480 p. (in Russian).

3. Лаломов А.В., Бочнева А.А., Чефранов Р.М., Трофимов В.А. Литолого-фациальное райониро- (an additional task is the decision of question about handling the localization point of toxic wastes also - hexachlorobenzene and others).

A complex ecological and mining-geological model is a basis for preparation of program management solution for two strategic directions:

- handling of the degraded territories of mining activities;

- handling of the remaining mineral resources (potassium-magnesium salts, brines).

\section{Conclusions}

The developed promising TES of complete type must provide a target problem solution in the case when the quantitative computer analysis of complex model does not lead to definite results, and the optimum decision receipt of target problem is only possible at the expert analysis of the results got on particular submodels of complex model. The scheme of classic TES (Fig. 1) is concretized for specific geological tasks (Fig. 2).

Authors see their further tasks as an elaboration of geological objects complex models, knowledge bases containing the sets of expert rules for interpretation of specific results of complex models for concrete objects, mathematical apparatus for treatment of knowledge bases, and finally, the development of the complete TES.

The authors are deeply grateful to V.M. Shestopalov, Secretary Academician of NASU Earth Sciences Department for this article analysis and his valuable comments.

вание и титан-циркониевая металлоносность Мансийской и Северо-Сосьвинской площадей Зауральского россыпного района. Литология и полез. ископаемые. 2010. № 4. С. 370-382.

Lalomov A.V., Bochneva A.A., Chefranov R.M., Trofimov V.A., 2010 Lithologic-facial regionalization and titanium-zirconium metalliferous Mansiisk and North-Sosva area of Transuralian district. Litologiya $i$ poleznye iskopaemye, no. 4, p. 370-382 (in Russian).

4. Смирнова А.С. Информационный анализ в геологии. Москва: Недра, 1985. 157 с.

Smirnova A.S., 1985. Informational analysis in geology. Moscow: Nedra, 157 p. (in Russian).

5. Хрущев Д.П., Лобасов А.П., Гейченко М.В., Ковальчук М.С., Ремезова А.Е., Босевская Л.П., Кирпач Ю.В., Степанюк А.В. Структурно-литологические модели перспективных осадочных формаций. Мінер. ресурси України. 2010. № 4. C. 39-44. 
Khrushchov D.P., Lobasov A.P., Geychenko M.V., Kovalchuk M.S., Remezova E.A., Bosevska L.P., Kyrpach Yu.V., 2010. Structural and lithological models of prospective sedimentary formations. Mineralni resursy Ukrainy, no. 4, p. 39-44 (in Russian).

6. Субботін C.О. Подання і обробка знань у системах штучного інтелекту та підтримки прийняття рішень: навч. посібник. Запоріжжя: ЗНТУ, 2008. $341 \mathrm{c}$.

Subbotin S.O., 2008. Presentation and treatment of knowledge at systems of artificial intelligence and support of decision-making. Zaporizhia: ZNTU, 341 p. (A manual for students) (in Ukrainian).

7. Таунсенд К., Фохт Д. Проектирование и программная реализация экспертных систем на персональных ЭВМ / [пер. с англ. В.А. Кондратенко, С.В. Трубицына]. Москва: Финансы и статистика, 1990. 320 с.

Townsend C., Feucht D., 1990. Designing and programming personal expert systems. Moscow: Finances and statistics, 320 p. (in Russian).

8. Хрущев Д.П., Лялько В.И., Харитонов О.М. Изоляция радиоактивных отходов в геологических формациях. Киев, 1993. 60 с. (Препринт / НАН Украины, ИГН; 93-3).

Khrushchov D.P., Lyalko V.I., Kharitonov O.M., 1993. Isolation of radioactive wastes in geological structures. Kiev: Institute of Geological Sciences, 60 p. (Preprint no. 93-3) (in Russian).

9. Хрущев Д.П., Оксенкруг Е.С. О связи прочностных свойств и структурно-текстурных особенностей каменной соли. Геол. журн. 1983. Т. 43, № 5 (212). C. 118-120.

Khrushchov D.P., Oksenkrug E.S., 1983. About a connection of strength properties and structuraltextural peculiarities of rock salt. Geologicheskiy zhurnal, vol. 43, no. 5 (212), p. 118-120 (in Russian).

10. Хрущев Д.П., Лобасов А.П. Принципы разработки цифровых структурно-литологических моделей осадочных формационных подразделений. Геол. журн. 2006. №2-3 (316). С. 90-102.

Khrushchov D.P., Lobasov A.P., 2006. The principles of elaboration of digital structural-lithological models of sedimentary structures subdivisions. Geologicheskiy zhurnal, no. 2-3 (316), p. 90-102 (in Russian).

11. Цифрова модель Солотвинської солянокупольної структури / Л.П. Босевська, Д.П. Хрущов, О.П. Лобасов, Ю.В. Кирпач. Зб. наук. праць ІГН НАН України. 2010. Вип. 3. С. 248-255.

Bosevska L.P., Khrushchov D.P., Lobasov A.P., Kyrpach Yu.V., 2010. Solotvino salt dome structure digital model. Scientific papers collection of IGS of NAS of Ukraine, iss. 3, p. 248-255 (in Ukrainian).

12. Khrushchov D.P., Bosevska L.P., Kyrpach Yu.V. (2010a). Human made intervention into salt massifs environment: mechanisms, factors, results and ecological problems - An Overview Paper Pre- sented at International Conference «GeoDarmstadt 2010» - Geosciences Secure the Future, Germany, Darmstadt, October 10-13, 2010, vol. 68, p. 305306.

Khrushchov D.P., Bosevska L.P., Kyrpach Yu.V. (2010a). Human made intervention into salt massifs environment: mechanisms, factors, results and ecological problems - An Overview Paper, International Conference «GeoDarmstadt 2010» - Geosciences Secure the Future, Germany, Darmstadt, October 10-13, 2010, vol. 68, p. 305-306 (in English).

13. Khrushchov D.P., Lobasov O.P., Kovalchuk M.S., Remezova O.O., Bosevska L.P., Kyrpach Yu.V. Target oriented expert systems of geological objects - the problem concept and results achieved. $7^{\text {th }}$ Euregeo European Congress on Regional Geoscientific Cartography and Sustainable Information Geo-Management Systems. Bologna, Italy, June $12^{\text {th }}-15^{\text {th }} 2012$, p. $765-766$.

Khrushchov D.P., Lobasov O.P., Kovalchuk M.S., Remezova O.O., Bosevska L.P., Kyrpach Yu.V. Target oriented expert systems of geological objects - the problem concept and results achieved. $7^{\text {th }}$ Euregeo European Congress on Regional Geoscientific Cartography and Sustainable Information Geo-Management Systems. Bologna, Italy, June $12^{\text {th }}-15^{\text {th }} 2012$, p. 765-766 (in English).

14. Khrushchov D.P., Lobasov O.P., Kovalchuk M.S., Remezova E.A., Kyrpach Yu.V. (2010b)Digital structural-lithological models of sedimentary formations: a tool of informational-analytical supervision for exploitation and protection of mineral resources and geological environment. An Overview Paper, International Conference «GeoDarmstadt 2010»Geosciences Secure the Future, Germany, Darmstadt, October 10-13, 2010, vol. 68, p. 306-307.

Khrushchov D.P., Lobasov O.P., Kovalchuk M.S., Remezova E.A., Kyrpach Yu.V. (2010b). Digital structural-lithological models of sedimentary formations: a tool of informational-analytical supervision for exploitation and protection of mineral resources and geological environment. An Overview Paper, International Conference «GeoDarmstadt 2010» - Geosciences Secure the Future, Germany, Darmstadt, October 10-13, 2010, vol. 68, p. 306307 (in English).

15. Krushchov D., Tabachny L. Deep Geological Disposal of Radioactive Waste in Ukraine. Geological Challenges in Radioactive Waste Isolation. Third Worldwide Review. Berkeley, California University, 2001 , p. $283-290$.

Krushchov D., Tabachny L. Deep Geological Disposal of Radioactive Waste in Ukraine. Geological Challenges in Radioactive Waste Isolation. Third Worldwide Review. Berkeley, California University, 2001, p. 283-290 (in English).

Received

March 17, 2015 